\title{
PENGARUH MODEL PEMBELAJARAN KONTEKSTUAL TERHADAP HASIL BELAJAR IPS DAN KESADARAN LINGKUNGAN SISWA KELAS VII SMP NEGERI 1 PETANG KABUPATEN BADUNG
}

\author{
I Dewa Gede Paramaweda ${ }^{1}$, I Putu Sriarta ${ }^{2}$, I Wayan Kertih ${ }^{3}$ \\ Program Studi Pendidikan IPS,Universitas Pendidikan Ganesha Singaraja \\ e-mail: gede.paramaweda ${ }^{1}$, putu.sriarta ${ }^{2}$, wayan.kertih $\left.{ }^{3}\right\} @$ pasca.undiksha.ac.id
}

\begin{abstract}
Abstrak
Penelitian ini bertujuan untuk mengetahui pengaruh beberapa variabel yaitu (1) hasil belajar IPS dan kesadaran lingkungan siswa secara simultan, antara kelompok siswa yang mengikuti model pembelajaran kontekstual dan model pembelajaran konvensional, (2) hasil belajar IPS antara kelompok siswa yang mengikuti model pembelajaran kontekstual dan model pemebelajaran konvensional, (3) kesadaran lingkungan antara kelompok siswa yang mengikuti model pembelajaran kontekstual dan model pemebelajaran konvensional. Populasi dalam penelitian ini adalah seluruh siswa kelas VII SMP Negeri 1 Petang Kabupaten Badung tahun ajaran 2017/2018 yang berjumlah 190 orang. Sample dalam penelitian ini menggunakan teknik class random sampling, yang mengambil sampledua kelompok siswa yaitu kelas VII A sebagai kelas kontrol dan kelas VII C sebagai kelas eksperiment. penelitian ini mengikuti rancangan eksperimen the post test only control group design. Data dalam penelitian ini dikumpulkan dengan menggunakan test pada variabel hasil belajar IPS dan kuesioner pada variabel kesadaran lingkungan. Data dianalisis dengan teknik manova satu jalur. Hasil penelitian menunjukkan bahwa: (1) secara simultan terdapat perbedaan hasil belajar IPS dan kesadaran lingkungan antara siswa yang mengikuti model pembelajaran kontekstual dengan siswa yang mengikuti model pembelajaran konvensional, (2) terdapat perbedaan hasil belajar IPS yang signifikan antara siswa yang mengikuti model pembelajaran kontekstual dengan siswa yang mengikuti model pembelajaran konvensional, (3) terdapat perbedaan kesadaran lingkungan yang signifikan antara siswa yang mengikuti model pembelajaran kontekstual dengan siswa yang mengikuti model pembelajaran konvensional. Berdasarkan ketiga temuan tersebut dapat disimpulkan bahwa model pembelajaran kontekstual lebih baik dibandingkan model pembelajaran konvensional dalam peningkatan hasil belajar IPS dan kesadaran lingkungan siswa.
\end{abstract}

Kata kunci: model pembelajaran kontekstual, hasil belajar IPS, kesadaran lingkungan.

\begin{abstract}
This study aimed to determine: (1) social studies learning outcomes and student environmental awareness simultaneously between groups of students who follow contextual learning model and conventional learning model, (2) social studies learning outcomes between groups of students who follow contextual learning model and conventional learning model (3) environmental awareness between groups of students who follow the contextual learning model and conventional learning model. The populations in this study were all students of VII grade at SMP Negeri 1 Petang,Badung Regency in academic year 2017/2018 which consists of 190 students. Class random sampling technique was used by the researcher to find out the sample for this research. The researcher randomly took two classes, namely VII $A$ as the control class and VII $C$ as the experimental class. This study followed by post-test only control group design asthe experimental design. The data were collected by using a test on social studies learning outcomes and questionnaires on the variable environmental awareness. One-way MANOVA technique was used in this study to analyzedthe data. The results showed that: (1) simultaneously, there were differences in social studies learning outcomes and environmental awareness among the students who followed the contextual learning model andthe students who followed the conventional learning model, (2) there were significant differences in social studies learning outcomes between students who followed the contextual learning model and students who followed conventional learning model, (3) there were significant differences in environmental awareness between students who followed the contextual learning model and students who followed conventional learning model. Based on the three findings, it can be concluded that
\end{abstract}


PIPS, Vol. 2 No. 1, Bulan April Tahun 2018

ISSN:2614-8366

the contextual learning model is better than the conventional learning model in improving social studies learning outcomes and student environmental awareness.

Keywords : contextual learning model, social studies learning outcomes, environmental awareness.

\section{PENDAHULUAN}

Pendidikan merupakan hal yang sangat penting diperoleh setiap individu. Dalam upaya mencerdaskan kehidupan bangsa, pemerintah telah menjamin hak seluruh Rakyat Indonesa atas pendidikan melalui Undang-undang 1945 pasal 31 tentang pendidikan dan kebudayaan. Sesuai dengan Undang-undang 1945 pasal 31 ayat 1 berubunyi "setiap warga negara berhak mendapatkan pendidikan". Dengan demikian mempertegas bahwa pendidikan juga merupakan hak asasi bagi setiap orang, dan pemerintah wajib menjaminnya.

$\mathrm{Hal}$ tersebut sejalan dengan tujuan adanya pendidikan itu sendiri yang termuat dalam Undang-undang Nomor 20 Tahun 2003 tentang Sistem Pendidikan Nasional pasal 3, yang berbunyi

"Pendidikan nasional berfungsi mengembangkan kemampuan dan membentuk watak serta peradaban bangsa yang bermartabat dalam rangka mencerdaskan kehidupan bangsa, bertujuan untuk berkembangnya potensi peserta didik agar menjadi manusia yang beriman dan bertakwa kepada Tuhan Yang Maha Esa, berakhlak mulia, sehat, berilmu, cakap, kreatif, mandiri, dan menjadi warga negara yang demokratis serta bertanggung jawab."

Berdasakan kutipan mengenai tujuan pendidikan nasional tersebut mengandung arti bahwa pendidikan tidak hanya membentuk manusia yang memiliki kemampuan di bidang keilmuan tertenu, namun juga dapat membentuk manusia dengan sikap dan akhlak yang baik. Sebagai upaya untuk mewujudkan integritas manusia yang seutuhnya diperlukan, pelaksanaan proses pendidikan yang efektif dan menyeluruh. Proses pendidikan pada umumnya selalu berhubungan atau tidak terlepas dari lingkungan.

Menurut Arif Rohman dalam Nugraheni (2015:2) hubungan pendidikan dengan lingkungan ibarat makhluk hidup dalam ekologi dinyatakan selalu hidup dalam habitatnya. Artinya hubungan antara proses pendidikan dengan lingkungan merupakan dua hal yang tidak bisa dipisahkan. Oleh sebab itu proses pembelajaran tidak semata-mata hanya membutuhkan lingkungan saja melainkan harus didukung dengan adanya lingkungan sekolah yang bersih dan sehat.

Ikhsan, dkk (2017:2) mengungkapkan tentang pentingnya lingkungan sekolah sehat sebagai berikut: (1) Sebagai upaya untuk pembinaan serta menciptakan lingkungan kehidupan sekolah yang sehat sangat penting karena lingkungan kehidupan sekolah yang sehat sangat diperlukan untuk meningkatkan kesehatan murid, guru, dan pegawai sekolah, serta peningkatan daya serap murid dalam proses belajar mengajar. Selain itu, (2) lingkungan sekolah yang sehat akan melahirkan siswa yang cerdas, bermutu, berwawasan lingkungan serta mampu menerapkan sikap cinta dan peduli lingkungan di sekolah.

Proses pendidikan pada umumnya selalu berhubungan atau tidak terlepas dari lingkungan. Menurut Arif Rohman dalam Nugraheni (2015:2) hubungan pendidikan dengan lingkungan ibarat makhluk hidup dalam ekologi dinyatakan selalu hidup dalam habitatnya. Artinya hubungan antara proses pendidikan dengan lingkungan merupakan dua hal yang tidak bisa dipisahkan. Oleh sebab itu proses pembelajaran tidak semata-mata hanya membutuhkan lingkungan saja melainkan harus didukung dengan adanya lingkungan sekolah yang bersih dan sehat.

Ikhsan, dkk (2017:2) mengungkapkan tentang pentingnya lingkungan sekolah sehat sebagai berikut: (1) Sebagai upaya untuk pembinaan serta menciptakan lingkungan kehidupan sekolah yang sehat sangat penting karena lingkungan kehidupan sekolah yang sehat sangat diperlukan untuk meningkatkan kesehatan murid, guru, dan pegawai sekolah, serta peningkatan daya serap murid dalam proses belajar mengajar. Selain itu, (2) lingkungan sekolah yang sehat akan melahirkan siswa yang cerdas, bermutu, berwawasan lingkungan serta mampu menerapkan sikap cinta dan peduli lingkungan di sekolah. Dengan adanya pendidikan lingkungan hidup akan memunculkan kesadaran terhadap lingkungan 
yang diwujudkan dalam kesediaan diri untuk menyatakan aksi-aksi yang dapat meningkatkan dan memelihara kualitas lingkungan dalam setiap prilaku yang berhubungan dengan lingkungan. Maka dengan adanya kesadaran terhadap lingkungan akan memunculkan suasana yang nyaman, tentram, dan bebas dari kerusakan lingkungan.

Peduli terhadap lingkungan berarti ikut melestarikan lingkungan sekolah dengan sebaik-baiknya, bisa dengan cara memelihara, mengelola, memulihkan serta menjaga lingkungan. Menurut Ikhsan, dkk (2017:1), lingkungan merupakan sesuatu yang mengelilingi kita, tempat kita berada dan melangsungkan kehidupan serta memenuhi segala keperluan hidup. Sebagai komponen yang sangat penting di dalam lingkungan, dalam interaksinya dengan lingkungan berupa kegiatan mengambil dan mengolah sumber daya alam, hendaknya manusia memiliki kesadaran terhadap lingkungan. Menurut Marfai dalam AlAnarwi, Amirun Mukminin (2014:19) jika manusia tidak memiliki kesadaran melestarikan lingkungan, maka lingkungan akan mengalami kerusakan dan memunculkan permasalahanpermasalahan lingkungan yang akan menimbulkan bencana yang berdampak pada bakhluk hidup dan lingkungan di sekitarnya.

Prilaku cinta lingkungan harus dipupuk terus menerus supaya nantinya menjadi manusia yang mempunyai kesadaran lingkungan yang tinggi. Hal tersebut harus dilaksanakan karena tingkat kesadaran para siswa mengenai lingkungan sekarang ini minim sehingga dapat menyebabkan kurangnya sikap kepedulian siswa terhadap lingkungan. Dasrita, dkk (2015 : 64) dalam penelitiannya mengungkapan bahwa kesadaran lingkungan siswa tergolong rendah. Rendahnya kesadaran lingkungan siswa tersebut muncul akibat dari rendahnya pengetahuan lingkungan, sikap lingkungan, serta prilaku lingkungan siswa. Kondisi tersebut terjadi pula di SMP Negeri 1 Petang.

Dari hasil observasi awal yang dilakukan peneliti di SMP Negeri 1 Petang didapati permasalahan sebagai berikut : (1) Siswa belum bisa merawat lingkungan (2) Siswa belum peduli terhadap kebersihan lingkungan sekolah (3) Masih ditemukan sampah kertas di laci sebagian siswa (4) Masih kurangnya plakat atau slogan untuk mengajak siswa menjaga kebersihan lingkungan (5) Upaya optimalisasi penggunaan lingkungan sekolah masih kurang (6) Pemberian hukuman-hukuman terhadap pelanggar atau pengotor lingkungan sekolah kurang memberikan pengaruh yang berarti.

Siswa belum bisa menghubungkan antara apa yang dipelajari dari guru dan bagaimana siswa menerapkan pengetahuan tersebut untuk digunakan dalam kehidupan sehari-hari. Hal ini dikarenakan cara siswa memperoleh pengetahuan belum tersentuh oleh strategi yang betul-betul bisa membantu siswa dalam membiasakan sikap tersebut. Selain itu para siswa juga kesulitan untuk memahami, karena metode mengajar yang selama ini digunakan oleh pendidik hanya terbatas pada metode konvensional contohnya ceramah. Siswa membutuhkan visualisasi, bukti otentik dari catatan yang ditulis di buku, atau teks singkat yang siswa baca, agar siswa bisa memahami berbagai hal yang dekat dengan kehidupannya. Oleh karena itu, diperlukan suatu strategi pembelajaran yang dapat menghubungkan pengetahuan dengan konteks kehidupan sehari-hari siswa yaitu melalui model pembelajaran kontekstual. Penggunaan model pembelajaran kontekstual terhadap pembentukan kesadaran lingkungan tepat disampaikan melalui pembelajaran IPS.

$\mathrm{Hal}$ ini cocok dengan esensi materi pelajaran IPS yaitu merupakan mata pelajaran yang memiliki fokus pada bagaimana manusia berinteraksi dengan lingkungannya. Hal tersebut akan mendorong siswa untuk membuat hubungan antara pengetahuan yang dimilikinya denga penerapan dalam kehidupan sebagai anggota keluarga dan masyarakat kelak serta mampu memperluas pengalaman, sedangkan guru akan memainkan perannya sebagai fasilitator yaitu membantu siswa mengaitkan antara materi yang diajarkan dengan situasi nyata.

Beberapa penelitian yang relevan dengan penelitian ini adalah (1) Nugraheni (2015) penelitian ini bertujuan untuk mengetahui pengaruh penggunaan Contextual Teaching and Learning (CTL) terhadap sikap peduli lingkungan siswa kelas IV di SD Negeri Selang, (2) penelitian yang dilakukan oleh Hermanto (2015) penelitian ini mengenai peningkatan keaktifan siswa melalui penerapan model Contextual Teaching and Learning (CTL), (3) penelitian yang dilakukan oleh Rahardiani, dkk (2015). Tujuan penelitian untuk mengetahui 
perbedaan pembelajaran CTL dilengkapi lab riil dan virtual pada materi pokok sistem koloid terhadap aktivitas belajar, prestasi belajar kognitif dan prestasi belajar afektif. Berdasarkan urian beberapa penelitian tersbut, penelitian yang berjudul Pengaruh Model Pembelajaran Kontekstual terhadap Hasil Belajar IPS dan Kesadaran Siswa yang akan peneliti lakukan, memiliki beberapa perbedaan sebagai berikut; (1) Belum ada penelitian serupa yang menggunakan dua variabel terikat, yaitu variabel hasil belajar IPS dan kesadaran lingkungan siswa, (2) Belum ada penelitian serupa yang berupaya menganalisis pengaruh variabel bebas berupa model pembelajaran kontekstual terhadap dua variabel terikat berupa hasil belajar IPS dan kesadaran lingkungan secara simultan. (3) Belum ada penelitian serupa dalam proses pengumpulan data khususnya variabel hasil belajar menggunakan angket dengan butir pertanyaan berbentuk essay yang dilengkapi rubric penilaian.

Tujuan dari penelitian ini adalah untuk menganalisis dan mendeskripsikan: (1) Pengaruh hasil belajaran IPS dan kesadaran lingkungan siswa secara simultan, antara kelompok siswa yang mengikuti model pembelajaran kontekstual dengan kelompok siswa yang mengikuti model pembelajaran konvensional pada siswa kelas VII SMP Negeri 1 Petang, (2) Pengaruh hasil belajar IPS antara kelompok siswa yang mengikuti model pembelajaran kontekstual dengan kelompok siswa yang mengikuti model pemebelajaran konvensional pada siswa kelas VII SMP Negeri 1 Petang. (3) Pengaruh kesadaran lingkungan antara kelompok siswa yang mengikuti model pembelajaran kontekstual dengan kelompok siswa yang mengikuti model pemebelajaran konvensional pada siswa kelas VII SMP Negeri 1 Petang.

\section{METODE}

Penelitian ini dilakukan pada siswa kelas VII SMP Negeri 1 Petang, yang terletak di Kecamatan Petang, Kabupaten Badung. Penelitian ini dilaksanakan mulai bulan Agustus sampai dengan Oktober 2018. Penelitian ini adalah penelitian kuasi eksperimen karena tidak semua variabel dan kondisi eksperimen dapat diatur dan dikontrol secara ketat. Peneltian ini mengikuti rancangan the post test only control group design Populasi dalam penelitian ini adalah seluruh siswa kelas VII SMP Negeri 1 Petang Kabupaten Badung tahun ajaran 2017/2018 yang berjumlah 190 orang.

Sample dalam penelitian ini menggunakan teknik class random sampling, sebelum melakukan penarikan sample terlebih dahulu dilakukan uji kesetaraan kelas menggunakan tenknik analisis ANAVA 1 jalur yang dibantu dengan Software IBM 22 SPSS Statistic fo Windows. Berdasarkan uji kesetaraan kelas dapat diketahui kelas yang memiliki tingkat kesetaraan yang sama meliputi kelas: VII A, VII B, VII D, dan VII E. Selanjutnya dilakukan penarikan sample secara acak, sehingga diperoleh yang dua kelompok siswa yaitu kelas VII A sebagai kelas kontrol dan kelas VII C sebagai kelas eksperiment.

Untuk mengumpulkan data mengenai hasil belajar dalam pembelajaran IPS dikumpulkan menggunakan tes pilihan ganda dengan empat pilihan (option), sedangkan untuk mengumpulkan data terkait kesadaran lingkungan siswa dikumpulkan menggunakan kuesioner yang dibuat berdasarkan syarat-syarat pembuatan instrument dengan modifikasi dari skala likert. Instrument pengumpulan data berupa tes hasil belajar dan kuesioner kesadaran lingkungan telah divalidasi baik secara isi oleh ahli maupun secara butir dengan mengunakan teknik analsis product moment, selanjutnya dilakukan pula uji reliabilitas terhadap instrument penelitian menggunakan teknik analisis Alpha Cronbach.

Pengujian hipotesis dilakukan dengan menggunakan manova untuk menguji ketiga hipotesis yang ada. Analisis menggunakan manova memerlukan beberapa uji prasyarat, antara lain: (1) distribusi normal, yaitu sebaran variabel terikat yang dibandingkan rataratanya mengikuti sebaran normal . Uji normalitas dilakukan dengan teknik KolmogorovSmirnov (K-S) menghasilkan nilai, (2) homogenitas varians, yaitu variansi antara kelompok satu dengan kelompok lainnya tidak berbeda secara signifikan, dilakukan dengan pengujian homogenitas Varian digunakan uji F-Leven's, (3) uji independensi variabel terikat dapat dipergunakan statistik uji Box-M. Uji hipoetesis dilakukan dengan teknik multivariate analisis of variance (Manova), seluruh uji tersebut diolah dengan bantuan software IBM 22 SPSS for Windows. 


\section{HASIL DAN PEMBAHASAN}

Variabel hasil belajar IPS siswa diukur dengan pilihan ganda, setelah dianalisis terhadap data yang terkumpul diperoleh skor minimum 60 , skor maksimum 96 , rentang 36 , rata-rata 77,19, standar deviasi 11,54 modus 68 , median 78 . Rata-rata skor data hasil belajar IPS yang mengikuti model pembelajaran kontekstual adalah 77,19 , sehingga termasuk pada ketegori sangat tinggi. Variabel kesadaran lingkungan siswa diukur dengan kuesioner, setelah dianalisis terhadap data yang terkumpul diperoleh skor minimum 11, skor maksimum 31 , rentang 20 , rata-rata 21,78 , standar deviasi 5,78 , modus 20 , median 22,50. Rata-rata skor data kesadaran lingkungan siswa yang mengikuti model pembelajaran kontekstual adalah 21,78 berada pada interval 16,67, sehingga termasuk pada kategori sedang.

Variabel hasil belajar IPS siswa diukur dengan pilihan ganda, setelah dianalisis terhadap data yang terkumpul diperoleh skor minimum 28 , skor maksimum 68 , rentang 40 , rata-rata 49, standar deviasi 11,03, modus 36 , median 48 . Rata-rata skor data hasil belajar IPS yang mengikuti model pembelajaran kontekstual adalah 49 berada pada interval 41,66, sehingga termasuk dalam kategori sedang. Variabel kesadaran lingkungan siswa diukur dengan kuesioner, setelah dianalisis terhadap data yang terkumpul diperoleh skor minimum 8 , skor maksimum 30 , rentang 22 , rata-rata 16,68 , standar deviasi 4,58 , modus 14 , median 16. Rata-rata skor data kesadaran lingkungan siswa yang mengikuti model pembelajaran kontekstual adalah 16,68 berada pada interval 16,67, sehingga termasuk ke dalam kategori sedang.

Terdapat tiga hipotesis yang diajukan dalam penelitian ini. Untuk menguji ketiga hipotesis penelitian tersebut menggunakan analisis Multivariat.

Selanjutnya untuk mengetahui perbedaan hasil belajar IPS dan kesadaran lingkungan siswa yang belajar dengan kedua model tersebut, dilakukan analisis menggunakan manova dengan bantuan IPM SPSS Statistic 22. Kriteria pengujian adalah jika harga F.Pillae Trace, Wilk Lambda, Hotelling's Trace, Roy's Largest Root memiliki signifikasi lebih kecil dari 0,05 maka hipotesis nol (Ho) ditolak dan berarti hipotesis alternatif (Ha) diterima. Jadi berdasarkan uji hipotesis ke-1 dapat disimpulkan bahwa terdapat perbedaan hasil belajar IPS dan kesadaran lingkungan siswa antara kelompok siswa yang dibelajarkan dengan model pembelajaran kontekstual dengan kelompok siswa yang dibelajarkan dengan pembelajaran konvensional pada siswa kelas VII SMP Negeri 1 Petang, Kabupaten Badung. Temuan penelitian ini sejalan dengan hasil penelitian yang dilakukan oleh Kersanwati (2013) dalam penelitian yang berjudul Korelasi Kualitas Pembelajaran Geografi dan Hasil Belajar terhadap Sikap Peduli Lingkungan Siswa Kelas XII IPS SMAN 1 Ponorogo. Hasil penelitian tersebut menunjukkan bahwa Hasil penelitian menyebutkan ada korelasi yang signifikan antara hasil belajar lingkungan hidup dengan sikap peduli lingkungan.

Ciri yang paling mendasar dalam proses belajar dengan metode kontekstual adalah adanya aktivitas intelektual yang tinggi. Siswa yang belajar dengan melibatkan aktivitas intelektual yang tinggi, akan menggunakan segala pengetahuan, keterampilan dan penalaran yang dimilikinya. Serta tidak hanya menggunakan dalil-dalil atau teori-teori. Pembelajaran tersebut akan mengoptimalkan pengorganisasian intelektual.

Berdasarkan analsisi hipoetesis ke-1, tampak bahwa nilai signifikasi lebih kecil dari 0,05 . Hal ini berarti hipotesis nol (Ho) ditolak dan hipotesis alternatif (Ha) diterima. Hasil ini sekaligus menunjukkan bahwa pembelajaran kontekstual lebih baik dari model pembelajaran konvensional. Berdasarkan hasil analisis terhadap hipoteisis ke-2 menunjukkan bahwa hasil belajar siswa yang dibelajarkan dengan model pembelajaran kontekstual dan model pembelajaran konvensional mehasilkan harga signifikasi $0,024<0,05$. Hal ini berarti, hipotesis nol $(\mathrm{Ho})$ ditolak dan hipotesis alternatif $(\mathrm{Ha})$ diterima. Hal ini mengindikasikan bahwa terdapat perbedaan hasil belajar IPS antara siswa yang mengikuti model pembelajaran kontekstual dengan siswa yang mengikuti model pembelajaran konvensional dimana hasil perhitungan menghasilkan siginifikansi nilai 0,00 lebih kecil dari 0,05. Temuan perbedaan pencapaian hasil belajar IPS tersebut dapat dijelaskan penyebabnya dari sudut 
pandang teoritik antara model pembelajaran kontekstual dengan model pembelajaran konvensional dimana keduanya memiliki karakteristik yang berbeda dilihat dari sintak pembelajaran. Dalam hal ini kegiatan pembelajaran yang menggunakan model pembelajaran kontekstual dapat lebih memberikan gambaran yang jelas dan nyata pada siswa dalam menyelesaikan permasalahan yang diberikan.

Sejalan dengan penelitian yang dilakukan oleh Astiti (2018) dalam penelitian yang berjudul Pengaruh Penerpan Model Pembelajaran Contekstual Teaching And Learning dan Quantum Teacihng terhadap Motivasi Berperstasi dan Hasil Belajar IPS Siswa Kelas VII SMP Negeri 1 Kediri. Penelitian tersebut menunjukkan bahwa hasil belajar IPS siswa yang mengikuti pembelajaran dengan metode contekstual teaching and learning lebih baik dari pada siswa yang mengikuti model pembelajaran quantum learning, hal ini sesuai dengan data hasil penelitian yang diperoleh yaitu skor rata-rata 85,300 , sedangkan hasil belajar IPS siswa yang mengikuti pembelajaran dengan pembelajaran Quantum Teaching pada siswa kelas VII SMP Negeri 1 Kediri. dengan skor rata-rata 73,267.

Analisis tersebut juga diperkuat oleh penelitian yang dilakukan oleh Setiawan (2008) yang berjudul Penerapan Pengajaran Kontestual Berbasis Masalah untuk Meningkatkan Hasil Belajar Biologi Siswa Kelas X SMA Laboratorium Singaraja. Hasil penelitian menunjukkan bahwa hasil belajar siswa yang mengikuti model pembelajaran kontekstual lebih tinggi secara signifikan dibandingkan dengan siswa yang mengikuti model pembelajaran konvensional. Hal ini sesuai dengan hasil penelitian yang menunjukkan terjadi peningkatan dari siklus I dengan persentase siswa yang mendapatkan nilai 7,5 ke atas sebesar $32,5 \%$, meningkat menjadi $47,5 \%$ pada siklus dua dan meningkat menjadi $80 \%$ pada siklus III.

Pembelajaran kontekstual adalah suatu prosedur pembelajaran yang sistematik dalam mengorganisasikan pengalaman belajar untuk mencapai tujuan belajar. Konsep belajar yang membantu guru mengaitkan materi pembelajaran dengan kehidupan nyata dan mendorong siswa membuat hubungan antara pengetahuan yang dimiliki dengan kehidupan sehari-hari. Dengan kata lain siswa dibekali dengan pengetahuan yang nantinya secara feksibel dapat diterpkan dalam kehidpannya untuk memecahkan seluruh persoalan yang ada di dunia nyata. Dari konsep ini diharapkan hasil pembelajaran akan lebih bermakna, lebih alamiah dalam bentuk kegiatan siswa belajar dan mengalami, bukan transfer pengetahuan dari guru ke siswa. Mengacu kepada hal tersebut, terdapat perbedaan proses pembelajaran kontestual dengan pembelajaran konvensional. Dengan adanya perbedaan pada proses pembelajaran, maka sangat mungkin jika hasil belajar IPS siswa yang mengikuti pembelajaran dengan model pembelajaran kontekstual berbasis masalah lebih baik daripada hasil belajar IPS siswa yang mengikuti pembelajaran konevnsional.

Berdasarkan hasil analisis terhadap hipotesisi ke-3, menunjukkan bahwa kesadaran lingkungan siswa yang dibelajarkan dengan model pembelajaran kontekstual dan model pembelajaran konvensional mehasilkan harga signifikasi $0,000<0,05$. Hal ini berarti, hipotesis nol $(\mathrm{Ho})$ ditolak dan hipotesis alternatif $(\mathrm{Ha})$ diterima.

Hasil penelitian menunjukkan bahwa terdapat perbedaan kesadaran lingkungan antara siswa yang mengkikuti model pembelajaran kontekstual dengan siswa yang mengikuti model pembelajaran konvensional. Hipotesis nol (Ho) dapat ditolak dan hipotesis alternatif (Ha) diterima, artinya terdapat perbedaan kesadaran lingkungan antara siswa yang mengikuti model pembelajaran kontekstual dengan siswa yang mengikuti model pembelajaran konvensional. Hal tersebut dilihat dari hasil uji hipotesis 3 menggunakan multivariat tes dimana hasil perhitungan menghasilkan nilai signifikan 0,00<0,05.

Secara umum bila ditinjau dari kategori baik pada data rata-rata kesadaran lingkungan siswa antara yang mengikuti model pembelajaran kontekstual maupun siswa yang mengikuti model pembelajaran konvensional berada pada kategori yang sama yaitu pada kategori sedang. Namun apabila dicermati data rata-rata kesadaran lingkungan tersebut memiliki selisih sebesar 5.11 antara data rata-rata sokor kesadaran lingkungan siswa yang mengikuti model pembelajaran konetekstual lebih tinggi dari pada data rata-rata skor kesadaran lingkungan siswa yang mengikuti model pembelajaran konvensional. 
Perbedaan ini dapat dijelaskan karena pengaruh model pembelajaran kontekstual memberikan kesempatan kepada siswa untuk dapat melatih dan mengembangkan kemampuan berfikir kompleks. Pembelajaran diawali dengan mengorientasikan siswa terhadap permasalahan nyata yang dianggap penting, menarik dan orisinil. Temuan dalam penelitian ini sejalan dengan penelitian yang dilakukan oleh Kristanti (2010:103) dengan fokus penelitian mengenai pengaruh metode pembelajaran kontekstual terhadap khususnya pada pemahaman masalah sosial berkaitan dengan pertumbuhan jumlah penduduk.

Penelitian tersebut menunjukkan ada pengaruh penerapan metode pembelajaran kontekstual terhadap pemahaman masalah social berkaitan dengan pertumbuhan penduduk pada siswa SMPN 18 Balikpapan, sehingga hipotesis yang menyatakan metode pembelajaran kontekstual dapat meningkatkan pemahaman masalah social berkaitan dengan pertumbuhan penduduk terbukti kebenarannya. Jhonson (2007:14) mengemukakan bahwa pembelajaran kontekstual didasarkan atas filosofi bahwa siswa mampu menyerap pembelajaran apabila mereka menangkap makna dalam materi yang mereka terima, dan mereka mengkap maka dalam tugas-tugas sekolah jika mereka bisa mengaitkan informasi baru dengan pengetahuan dan pengalaman yang sudah mereka miliki sebelumnya.

Hal tersebut dapat diartikan bahwa pengamatan suatu fenomena yang terjadi di lingkungan sekitar siswa selanjutnya dikontruksikan kembali dalam proses pembelajaran di kelas sesuai dengan indikator-indikator pencapaian yang direncanakan dalam proses pembalajaran, begitu pula terkait kesadaran lingkungan siswa, melalui model pembelajaran kontekstual siswa didorong dapat memecahkan masalah lingkungan yang terjadi di lingkungan sekitarnya dengan dasar kontrusksi fikiran yang telah diperoleh melalui pengamatan sehari-hari.

\section{PENUTUP}

Berdasarkan pengajuan hipotesis dan pembehasan maka dapat ditarik kesimpulan bahwa model pembelajaran kontekstual dapat menghasilkan hasil belajar IPS dan kesadaran lingkungan siswa yang lebih baik dari pada model pembelajaran konvensional. Adapun secara rinci simpulan dari penelitian ini dapat dijelaskan sebagai berikut.

Pertama, secara bersama-sama atau simultan terdapat perbedaan hasil belajar IPS dan kesadaran lingkungan antara siswa yang mengikuti model pembelajaran kontekstual dengan siswa yang mengikuti model pembelajaran konvensional.

Kedua, terdapat perbedaan hasil belajar IPS yang signifikan antara siswa yang mengikuti model pembelajaran kontekstual dengan siswa yang mengikuti model pembelajaran konvensional. Hasil belajar siswa yang mengikuti model pembelajaran kontekstual lebih baik dari pada siswa yang mengikuti model pembelajaran konvensional. Kualifikasi hasil belajar IPS siswa yang mengikuti model pembelajaran kontekstual berada pada kategori tinggi sedangkan hasil belajar IPS siswa yang mengikuti model pembelajaran konvensional berada pada kategori sedang.

Ketiga, terdapat perbedaan kesadaran lingkungan yang signifikan antara siswa yang mengikuti model pembelajaran kontekstual dengan siswa yang mengikuti model pembelajaran konvensional. Kesadaran lingkungan siswa yang mengikuti model pembelajaran kontekstual lebih baik dari pada siswa yang mengikuti model pembelajaran konvensional. Walapun dalam kualifikasi kesadaran lingkungan siswa yang mengikuti model pembelajaran kontkstual dengan siswa yang mengikuti model pembelajaran konvensional cenderung berada pada kategori yang sama yaitu sedang.

Berdasarkan simpulan dan implikasi penelitian di atas, maka dapat diajukan beberapan saran untuk meningkatkan kualitas pembelajaran IPS kedepannya adalah sebagai berikut: (1) Model pembelajaran kontekstual perlu lebih maksimal untuk alternatif model pembelajaran yang dapat dialkukan melalui kegiatan-kegiatan seminar, workshp, pelatihanpelatihan maupun dalam pertemuan KKG, karena melalui pembelajaran ini proses pembelajaran lebih efektif dan memungkinkan peserta didik akan lebih aktif, kreatif, dan memotivasi belajar siswa dalam mencapai tujuan pembelajaran, (2) Kepada guru IPS khsusnya, disarankan untuk mencoba menggunakan model pembelajaran kontekstual pada siswa dikarenakan model pembelajaran kontkestual telah terbukti dapat meningkatkan hasil 
belajar IPS lebih tinggi dibandingkan menggunakan model pembelajaran konvensional, (3) Penelitian ini tergolong dalam jenis eksperimen semu oleh karena itu tidak seluruh variabel yang dapat memenuhi hasil penelitian dapat dikendalikan sehingga perlu kiranya dilakukan penelitian yang sama dengan desain eksperimen murni agar dapat menggambarkan hasil penelitian yang lebih optimal, (4) bagi para peneliti perlu diadakan penelitian sejenis yang lebih inovatif dan dengan melibatkan sampel yang lebih banyak, tingkat kelas lebih beragam, serta diharapkan hasil penelitiannya lebih akurat sehingga hasilnya betul-betul member informasi yang lebih baik.

\section{UCAPAN TERIMAKASIH}

Penulis menyampaikan terimakasih dan penghargaan yang sebesar-besarnya kepada: (1) Dr. Drs. I Putu Sriartha, MS, sebagai pembimbing I yang telah dengan sabar membimbing, mengarahkan, dan memberikan motivasi yang demikian bermakna, sehingga penulis mampu melewati berbagai kerikil dalam perjalanan studi dan penyelesaian proposal tesis ini, (2) Dr. Drs. I Wayan Kertih, M.Pd, sebagai pembimbing II, yang telah dengan gaya dan pola komunikasi yang khas, telah melecut semangat, motivasi, dan harapan pemulis selama penelitian dan penulisan naskah, sehingga tesis ini dapat terwujud dengan baik sesuai harapan, (3) Bapak Rektor Universiatas Pendidikan Ganesha, yang telah memberikan bantuan secara moral dan memfasilitasi berbagai kepnetingan studi, selama penulis menempuh perkuliahan di Pancasarjana Universitas Pendidikan Ganesha, (4) Bapak Direktur Pascasarjana Universiatas Pendidikan Ganesha dan staf, yang telah banyak membantu selama penulis mengikuti studi dan menyelesaikan penulisan proposal teis ini, (5) Bapak Ketua Program Studi Pendidikan IImu Pengetahuan Sosial dan staf dosen pengajar yang telah banyak membantu dan memotivasi penulis selama perjalanan studi dan penyusunan proposal tesis ini, (6) Kepala Sekolah SMP Negeri 1 Petang yang telah memberikan izin dan bantuan administratif guna melancarkan penyusunan proposal tesis ini: (1) Rekan-rekan seangkatan di Program Studi Pendidikan Pengetahuan Ilmu Sosial yang dengan karakternya masing-masing telah banyak berkontribusi membentuk kedirian penulis selama mejalani studi dan penyelesaian proposal tesis ini.

\section{DAFTAR RUJUKAN}

Al-Anarwi, Amirul Mukminin. 2014. Strategi Pembentukan Karakter Peduli Lingkungan di Sekolah Adiwiyata Mandiri. Jurnal Ta'dib, Vol 19, No2. IAIN Sulthan Thahah Saifuddin Jambi.

Astiti, Ni Nyoman Sari. 2018. Pengaruh Penerapan Model Pembelajaran Contekstual Teaching and Learning, Jurnal Pendidikan Ekonomi, (6), (1), Tersedia pada: https://ejournal.undiksha.ac.id/index.php/EKU/article/download/14241/856. (Diakses pada: 25 Desember 2018)

Dasrita, dkk, 2015, Kesadaran Lingkungan Siswa Sekolah Adiwiyata, Jurnal Dinalima Lingkungan Indonesia, 2 (1), Tersedia pada: http://download.garuda.ristekdikti.go.id/article.php?article=339103\&val=7633\&title=Kes adaran\%20Lingkungan\%20Siswa\%20Sekolah\%20Adiwiyata. (Diakses pada: 20 Desember 2018)

Hermanto. 2015. Pengaruh Model Pembelajaran Kontekstual (CTL) terhadap Keaktifan Siswa Kelas IV pada Mata Pelajaran PKN di Sekolah Dasar Negeri 1 Warungbambu. Jurnal Pedagogik Vol 3. No 1. Bekasi; Universiatas Islam.

Ikhsan, Andi, dkk, 2017, Pemanfaatan Lingkungan Sekolah sebagai Sumber Belajar di SD Negeri 2 Teunom Aceh Jaya, Jurnal Ilmiyah Pendidikan Sekolah Dasar, 2 (1), https://media.neliti.com/media/publications/187661-ID-pemanfaatan-lingkungansekolah-sebagai-s.pdf. (Diakses pada: 15 November 2018). 
Jhonson, Elaine B. 2007. Contekstual Teaching \& Learning. Bandung: Penerbit MLC

Kristanti, Wulan. 2010. Pengaruh Model Pembelajaran Kontekstual terhadap Hasil Belajar IPS Geografi Kelas VIII SMPN 18 Balikpapan Ditinjau dari Motivasi Belajar Siswa Tahun Pelajaran 2009/2010. Tesis. (tidak diterbitkan). Surakarta: Program Pascasarjana Universitas Sebelas Maret.

Nugraheni, Rini Ayu Sih, 2015, Pengaruh Contextual Teaching and Learning (CTL) terhadap Sikap peduli Lingkungan Siswa Kelas IV di SD Negeri Selang Kecamatan Wonosari Kabupaten Gunungkidul. Jurnal Pendidikan Guru Sekolah Dasar Edisi 14, http://journal.student.uny.ac.id/ojs/index.php/pgsd/article/viewFile/1178/1051. Diakses pada: 15 November 2018).

Kersnawati, Novia. 2013. Korelasi Kualitas Pembelajaran Geografi dan Hasil Belajar terhadap Sikap Peduli Lingkungan Siswa Kelas XII IPS SMAN 1 Ponorogo. Jurnal Pendidikan Humaniora, Hal. 298-303, 1(3)

Rahardiana, Galuh, dkk. 2015. Pengaruh Pembelajaran Contextual Teaching and Learning (CTL) Dilengkapi Lab Riil dan Virtual terhadap Aktivitas dan Prestasi Belajar Siswa pada Materi Pokok Sistem Koloid Kelas XI IPS Semester Genap SMANegeri 1 Pulokulon tahun Pelajaran 2013/2014. Jurnal Pendidikan Kimia Vol 4. No 1. Universiatas Sebelas Maret: Program Studi Pendidikan Kimia.

Setiawan, I Gusti Agung Nyoman. 2008. Penerapan Pengajaran Kontekstual Berbasis Masalah untuk Meningkatkan Hasil Belajar Biologi Siswa Kelas X SMA Laboratorium Singaraja. Jurnal Penelitian dan Pengembangan Pendidikan Vol 2, No 1, https://s3.amazonaws.com/academia.edu.documents/33144563/IGAN Setiawan.pdf?A WSAccessKeyld=AKIAIWOWYYGZ2Y53UL3A\&Expires $=1558854698 \&$ Signature $=0 T s 8$ NV\%2BCAXrYNP3FFqul5y0psqE\%3D\&response-contentdisposition=inline\%3B\%20filename\%3DJurnal PENERAPAN PENGAJARAN KONTE KSTUAL.pdf. (Diakses pada: 15 Mei 2019)

UUD. 1945. Pasal 31 Tentang Pendidikan dan Kebudayaan. Jakarta: Sekretariat Negara.

Undang-Undang RI Nomor 20 Tahun2003. Pasal 3 Tentang Sistem Pendidikan Nasional. Jakarta: Sekretariat Negara 